\title{
Methodiek schoolverlatersinformatiesysteem 1997
}

Citation for published version (APA):

Willems, E., \& Welters, R. A. M. H. M. (1999). Methodiek schoolverlatersinformatiesysteem 1997.

Researchcentrum voor Onderwijs en Arbeidsmarkt, Faculteit der Economische Wetenschappen. ROA Working Papers No. 1 https://doi.org/10.26481/umarow.1999001

Document status and date:

Published: 01/01/1999

DOI:

10.26481/umarow.1999001

Document Version:

Publisher's PDF, also known as Version of record

\section{Please check the document version of this publication:}

- A submitted manuscript is the version of the article upon submission and before peer-review. There can be important differences between the submitted version and the official published version of record.

People interested in the research are advised to contact the author for the final version of the publication, or visit the DOI to the publisher's website.

- The final author version and the galley proof are versions of the publication after peer review.

- The final published version features the final layout of the paper including the volume, issue and page numbers.

Link to publication

\footnotetext{
General rights rights.

- You may freely distribute the URL identifying the publication in the public portal. please follow below link for the End User Agreement:

www.umlib.nl/taverne-license

Take down policy

If you believe that this document breaches copyright please contact us at:

repository@maastrichtuniversity.nl

providing details and we will investigate your claim.
}

Copyright and moral rights for the publications made accessible in the public portal are retained by the authors and/or other copyright owners and it is a condition of accessing publications that users recognise and abide by the legal requirements associated with these

- Users may download and print one copy of any publication from the public portal for the purpose of private study or research.

- You may not further distribute the material or use it for any profit-making activity or commercial gain

If the publication is distributed under the terms of Article $25 \mathrm{fa}$ of the Dutch Copyright Act, indicated by the "Taverne" license above, 
Methodiek Schoolverlatersinformatiesysteem 1997

ROA-W-1999/1

Ed Willems en Riccardo Welters

Researchcentrum voor Onderwijs en Arbeidsmarkt

Faculteit der Economische Wetenschappen en Bedrijfskunde Universiteit Maastricht

Maastricht, december 1998 
ISBN 90-5321-248-5

Sec98.241/RW 
Inhoudsopgave

Bladzijde

Voorwoord

1 Inleiding 1

2 Schoolverlatersonderzoeken 1

3 Dataverwerking en weging 3

4 Dekkingsgraad en respons $\quad 7$

5 Non-respons 12

6 Besluit $\quad 18$

$\begin{array}{ll}\text { Literatuur } & 19\end{array}$

$\begin{array}{ll}\text { Appendix A: Kernvragenlijst } & 21\end{array}$ 


\section{Voorwoord}

Dit werkdocument gaat in op de methodiek die in het uitvoeringsjaar 1997 is gehanteerd binnen het schoolverlatersonderzoek, zoals dat door het ROA wordt uitgevoerd. Dit betreft de enquêtes Registratie van Uitstroom en Bestemming van Schoolverlaters (RUBS), HBO-Monitor en WO-Monitor. Sinds 1996 is het ROA-schoolverlatersonderzoek in vergaande mate geïntegreerd. Hierdoor is een vergelijkbaar systeem ontstaan met gegevens over schoolverlaters uit vrijwel het gehele secundair en tertiair onderwijs, vooralsnog met uitzondering van een groot gedeelte van het wetenschappelijk onderwijs. Vanaf volgend jaar maakt ook vrijwel het gehele wetenschappelijk onderwijs deel uit van dit schoolverlatersinformatiesysteem. In het kader van het onderzoek binnen dit informatiesysteem zijn in 1998 onder andere het rapport Schoolverlaters tussen onderwijs en arbeidsmarkt 1997 en een bijbehorende bijlage Statistische bijlage gepubliceerd (ROA, 1998a en 1998b). Daarnaast is een specifieke rapportage verschenen over de arbeidsmarktpositie van de afgestudeerden van het HBO (Allen en Ramaekers, 1998 en ROA/DESAN, 1998). Voor de lerarenopleiding is een aparte rapportage verschenen (Van der Linden en Van der Velden, 1998). Ook over de afgestudeerden van het kunstvakonderwijs verschijnt, begin 1999, een specifiek rapport. Tevens zijn de belangrijkste resultaten van de WO-Monitor Economie in een landelijke rapportage samengebracht (Van der Velden, Welters en Willems, 1998). In 1997 zijn in het kader van het schoolverlatersinformatiesysteem enkele 'pilot'-onderzoeken uitgevoerd. Dit betreft enquêtes onder schoolverlaters van de beroepsbegeleidende leerweg, ex-cursisten van het Voortgezet Algemeen Volwassenen Onderwijs (VAVO) en onder voortijdig schoolverlaters. Hierover zal in aparte rapportages zowel methodologisch als inhoudelijk verslag worden gedaan.

Het Schoolverlatersinformatiesysteem wordt financieel mogelijk gemaakt door de Ministeries van Onderwijs, Cultuur en Wetenschappen, Sociale Zaken en Werkgelegenheid en Landbouw, Natuurbeheer en Visserij, het Expertisecentrum voor Loopbaanvraagstukken LDC, de HBORaad en de deelnemende faculteiten en universiteiten aan de WO-Monitor. Bij de uitvoering van het onderzoek werkt het ROA samen met DESAN Marktonderzoek b.v. te Amsterdam. Binnen het ROA is de projectleiding van het Schoolverlatersinformatiesysteem in handen van dr. R.K.W. van der Velden en drs. E.J.T.A. Willems. Dit werkdocument is samengesteld door drs. R.A.M.H.M. Welters en drs. E.J.T.A. Willems. Verder hebben aan het Schoolverlatersinformatiesysteem 1997 meegewerkt dr. J.P. Allen, H. C. E. van Dijk, drs. T.G. Huijgen, A.M. Kleijnen, drs. A.S.R. van der Linden, J.M.J.A. Pisters, drs. G.W.M. Ramaekers, E.M.H.P. Soudant en dr. M.H.J. Wolbers (allen werkzaam bij ROA), alsmede drs. K.R. Becker, drs. H. Van Dongen, drs. ing. Pagrach en ing. J.J. Rutjes (allen werkzaam bij DESAN Marktonderzoek). 


\section{Inleiding}

Door het ROA worden jaarlijks enkele grootschalige schoolverlatersonderzoeken uitgevoerd. Enerzijds betreft dit een onderzoek onder de schoolverlaters van het Algemeen Voortgezet Onderwijs (AVO), het Voorbereidend Beroepsonderwijs (VBO) ${ }^{1}$ en de beroepsopleidende leerweg (BOL) van het Middelbaar Beroepsonderwijs (MBO) aan de hand van de enquête Registratie van Uitstroom en Bestemming van Schoolverlaters (RUBS). Anderzijds is dit een onderzoek onder de afgestudeerden van het Hoger Beroepsonderwijs (HBO) in de $\mathrm{HBO}$ Monitor. Daarnaast wordt onderzoek verricht onder de afgestudeerden van de Universiteit Maastricht en de Technische Universiteit Delft, alsmede onder de afgestudeerden van de economische faculteiten van de Erasmus Universiteit Rotterdam, de Katholieke Universiteit Brabant, de Universiteit van Amsterdam en de Vrije Universiteit in de WO-Monitor. Deze schoolverlatersonderzoeken vormen onder andere de basis voor een aantal landelijke publicaties, zoals de recent verschenen rapporten Schoolverlaters tussen onderwijs en arbeidsmarkt 1997 en De arbeidsmarktpositie van afgestudeerden van het hoger beroepsonderwijs; HBOMonitor 1997 en Economen op de arbeidsmarkt 1997; WO-Monitor economie.

Dit werkdocument vormt een methodologische aanvulling op deze reeds verschenen rapporten. Er zal met name ingegaan worden op de gehanteerde methodiek, de respons en op het uitgevoerde non-responsonderzoek. De opzet van de rest van dit werkdocument is als volgt. Allereerst wordt in paragraaf 2 een uiteenzetting gegeven over het doel en de opzet van de schoolverlatersonderzoeken. Vervolgens wordt in paragraaf 3 ingegaan op de dataverwerking en de weging van de gegevens. In paragraaf 4 wordt daarna een overzicht gegeven van de dekkingsgraad en de respons. Paragraaf 5 bevat het verslag van het nonresponsonderzoek. In paragraaf 6 wordt dit werkdocument ten slotte kort samengevat.

\section{Schoolverlatersonderzoeken}

Doel

De schoolverlatersenquêtes van het ROA zijn gericht op het monitoren en analyseren van de bestemming van (gediplomeerde) schoolverlaters in het vervolgonderwijs en op de arbeidsmarkt. Aandachtspunten daarbij zijn het individuele keuzegedrag ten aanzien van (vervolg-) onderwijs, de arbeidsmarktpositie van opleidingen, het zoekgedrag en het beroepsmatig functioneren van schoolverlaters, hun initiële loopbanen en de evaluatie van het curriculum.

Binnen de schoolverlatersonderzoeken van het ROA kunnen twee componenten worden onderscheiden: een toepassingscomponent en een onderzoekscomponent. De toepassingscomponent richt zich op de zorg van individuele onderwijsinstellingen voor de

1. In 1997 is voor het eerst ook het IVBO in het onderzoek opgenomen. 
onderwijskwaliteit en de afstemming van het onderwijs op de behoeften van de arbeidsmarkt. Daarvoor worden zogenaamde instellingsrapportages opgesteld waarin de onderwijsinstellingen informatie krijgen over hun 'eigen' afgestudeerden, waar relevant afgezet tegen het landelijke beeld. Hiermee kunnen management, studierichtingsleiders en decanaat een indruk verkrijgen van het externe rendement van de eigen afgestudeerden.

De onderzoekscomponent van het schoolverlatersonderzoek, aangeduid als het Schoolverlatersinformatiesysteem, heeft als doel het analyseren van het doorstroompatroon van schoolverlaters naar vervolgonderwijs en het transitieproces van school naar werk. De resultaten hiervan worden onder meer gepubliceerd via algemeen toegankelijke landelijke rapportages. Hierin ligt het accent op (de ontwikkelingen in) het intredeproces van schoolverlaters, de kansen op het vinden van werk, de kwaliteit van het werk en het keuzegedrag van schoolverlaters ten aanzien van mogelijke vervolgopleidingen en de kwaliteit van de aansluiting die daarbij wordt ondervonden.

\section{Opzet}

Zoals reeds eerder is aangegeven, vormt een drietal schoolverlatersonderzoeken, te weten RUBS, de HBO-Monitor en de WO-Monitor, de basis van het Schoolverlatersinformatiesysteem. Voor al deze schoolverlatersonderzoeken geldt dat onderwijsinstellingen zelf aangeven of zij met (een deel van) hun schoolverlaters of afgestudeerden willen deelnemen². Er is derhalve geen sprake van een aselecte steekproef. Mochten er echter 'witte vlekken' in de deelname ontstaan - zowel naar opleidingsrichting of regio - dan wordt een aanvullende steekproef getrokken. In 1997 is een aanvullende steekproef getrokken voor de opleidingsrichtingen IVBO economie (landelijk), VBO techniek (regio oost en zuid), VBO gezondheidszorg (regio oost) en VWO (regio oost). Voor het WO is het onderzoek vooralsnog beperkt tot enkele deelnemende universiteiten en faculteiten. Vanaf komend jaar zal er in VSNU-verband een WO-Monitor onder de afgestudeerden van alle Nederlandse universiteiten worden gehouden.

Sinds het uitvoeringsjaar 1996 wordt het schoolverlatersonderzoek van het ROA uitgevoerd volgens een geïntegreerd model, waarbij één meetmoment en één kernvragenlijst wordt onderscheiden. In de praktijk betekent dit dat in de periode oktober, november en december 1997 ruim 85.000 schoolverlaters en afgestudeerden van het school-/studiejaar 1995/1996 zijn benaderd met een schriftelijke vragenlijst. Wanneer schoolverlaters na ruim een maand de vragenlijst nog niet teruggestuurd hebben, wordt een rappèl verstuurd. In sommige gevallen is tevens telefonisch gerappelleerd.

2. De RUBS-enquête wordt bij de scholen aangeboden onder verantwoordelijkheid van het LDC. De HBO-Monitor wordt bij de hogescholen aangeboden onder auspiciën van de HBO-Raad. Het ROA biedt zelf de WO-Monitor aan bij de universiteiten of faculteiten. Binnen het agrarisch onderwijs wordt zowel de RUBS-enquête als de HBO-Monitor aangeboden door bureau Arbeidsmarktonderzoek van STOAS te Wageningen. 
Ofschoon de vragenlijsten in de kern gelijk zijn, is ook in het uitvoeringsjaar 1997 gebruik gemaakt van verschillende vragenlijsten, om zodoende recht te doen aan de verschillen die er tussen de diverse onderwijsniveaus of -sectoren bestaan. Binnen RUBS zijn aparte lijsten gebruikt voor de schoolverlaters van MAVO/HAVO/VWO, van IVBO, van VBO en van MBO. Voor het agrarisch onderwijs op zowel VBO- als MBO-niveau zijn specifieke vragenlijsten gebruikt. Binnen de HBO-Monitor is een aparte vragenlijst opgesteld voor de afgestudeerden van het landbouwonderwijs, het pedagogisch onderwijs en de opleiding HBO elektrotechniek Daarnaast zijn onder de naam Kunsten-Monitor twee specifieke vragenlijsten opgesteld voor afgestudeerden van het kunstonderwijs, respectievelijk vragenlijsten voor HBO Beeldende Kunst en Vormgeving en HBO Muziek en Theater. Om een hogere respons te bereiken, is onder afgestudeerden van het kunstonderwijs die de schriftelijke vragenlijst niet hebben teruggestuurd een beperkt gedeelte van de vragenlijsten telefonisch afgenomen. Afgestudeerden van het Hoger Pedagogisch Onderwijs die in eerste instantie niet hebben gereageerd op de schriftelijke enquête zijn eveneens integraal telefonisch benaderd.

De vragenlijsten van het uitvoeringsjaar 1997 bestaan uit een viertal hoofd-onderwerpen: algemeen (geslacht, leeftijd e.d.), onderwijsloopbaan, arbeidsmarktintrede en een thematisch gedeelte. Binnen de vragenlijsten voor het AVO en het VBO ligt de nadruk op de doorstroom naar het vervolgonderwijs en de redenen van eventuele uitval. Tevens wordt in deze vragenlijsten uitgebreid stilgestaan bij de rol van studie- en beroepskeuzebegeleiding. Er wordt slechts in beperkte mate ingegaan op de arbeidsmarktintrede van schoolverlaters. In de overige vragenlijsten ligt de nadruk juist op het transitieproces van school naar werk en wordt minder vergaand gevraagd naar de doorstroom naar vervolgonderwijs. In het thematisch gedeelte is in 1997 aandacht besteed aan de verwachtingen die de afgestudeerden hebben over hun toekomstige carrière. Overigens is dit thema-deel alleen opgenomen in de vragenlijsten voor schoolverlaters van het MBO en hoger $^{3}$.

\section{Dataverwerking en weging}

Nadat de vragenlijsten verzameld zijn, start het dataverwerkingsproces. Hierbij wordt de informatie op de vragenlijsten omgezet tot een bestand dat geschikt is voor het uitvoeren van analyses. Dit proces van dataverwerking bestaat uit een aantal stappen: de codering van enkele vragen met 'open' antwoordcategorieën (waaronder vervolgopleiding, beroep, bedrijfssector), de data-entry, de opschoning van het bestand voor mogelijke inconsistenties ('datacleaning') en de uitbreiding van het bestand met nieuwe variabelen. Vervolgens wordt het bestand gewogen, zodat op basis van de gegevens landelijk representatieve uitspraken kunnen worden gedaan.

3. Zie bijlage A voor een overzicht van het kerndeel van de vragenlijst. 
De vragenlijsten bevatten voor het merendeel gesloten antwoordcategorieën, waarbij de respondenten kunnen kiezen uit een aantal voorgedrukte mogelijkheden. In een beperkt aantal gevallen dienen de schoolverlaters zelf een numerieke waarde in te vullen, bijvoorbeeld bij leeftijd, inkomen en aantal gewerkte uren. Bij enkele vragen wordt echter gebruik gemaakt van een volledig 'open' vraagstelling, waarbij de schoolverlaters zelf het antwoord op de vraag moeten omschrijven. Dit is met name het geval bij vragen waar het gaat om:

- $\quad$ soort (vervolg- en voor-)opleiding;

- beroep;

- bedrijfssector;

- (woon- of werk-)gemeente.

$\mathrm{Bij}$ deze vragen worden de alfanumerieke antwoorden van de respondenten gecodeerd volgens vooraf opgestelde classificaties. Voor de opleidingsvragen wordt daarbij gebruik gemaakt van een speciaal voor dit doel door het ROA opgestelde opleidingsclassificatie, waarin alle in Nederland voorkomende (reguliere) opleidingen zijn opgenomen ${ }^{4}$. Beroep en bedriifssector worden gecodeerd volgens de Standaard Beroepen Classificatie 1992 (SBC92) en de Standaard Bedrijfsindeling 1993 (SBI93) van het CBS. Overigens zijn beide classificaties, waar relevant, door het toevoegen van een extra digit verder verbijzonderd. Gemeenten worden gecodeerd volgens de gemeentecodes die door het CBS in het meest recente Plaatsnamenregister worden gehanteerd.

De aldus verkregen 'ruwe' gegevens worden vervolgens onderworpen aan een uitgebreide kwaliteitscontrole. Doel van deze controles is eventuele onvolkomenheden, fouten en inconsistenties te achterhalen en zo mogelijk te corrigeren ${ }^{5}$. Het proces van kwaliteitscontrole van de gegevens is in een vijftal fasen onderverdeeld:

1. Eerste controle: dit is een algemene controle om te achterhalen of er bij de data-entry problemen zijn opgetreden en of de gegevens ten aanzien van de gevolgde opleiding juist zijn.

2. Controle op stringvariabelen: hierin wordt bekeken of er bij de vragen met een antwoordcategorie "anders, namelijk ..." bepaalde grote groepen kunnen worden onderscheiden.

3. Controles per blok ${ }^{6}$ : in deze fase wordt gecontroleerd of de antwoorden op de vragen die bij elkaar horen, overeen kunnen komen. Een voorbeeld kan dit verduidelijken. Stel dat

4. De Standaard Onderwijs Indeling (SOI) van het CBS is voor het schoolverlatersonderzoek niet geschikt. Deze classificatie is sterk verouderd en maakt enkele belangrijke onderscheiden binnen het onderwijssysteem niet. Zo wordt bijvoorbeeld binnen de SOI het leerlingwezen, kort MBO en MBO niet van elkaar onderscheiden. Ook moeten nieuwe opleidingen vaak onder de noemer 'niet eerder geclassificeerd' worden ondergebracht. Overigens voorziet de ROA classificatie wel in een koppeling met de SOI.

5. Overigens is een groot aantal controles reeds in de data-entry opgenomen. Dit betreft met name controles op grenswaarden en controles op de in de vragenlijsten gehanteerde routings.

6. Blokken in de vragenlijsten zijn bijvoorbeeld "Gevolgde opleiding", "Vervolgopleiding", "Belangrijkste bezigheden" en "Kenmerken huidige functie". 
het antwoord op de vraag "volg je deze vervolgopleiding nog steeds" ontbreekt, terwijl de vraag waarom de schoolverlater gestopt is wel ingevuld is. In dat geval wordt het ontbrekende antwoord op de eerste vraag vervangen door "nee, voortijdig verlaten".

4. Controles over de blokken heen: hierin wordt nagegaan of de antwoorden op de vragen van verschillende blokken met elkaar overeenstemmen. Bijvoorbeeld: wanneer de eerste maanden van de 'kalender' met belangrijkste bezigheden per maand niet ingevuld zijn en de eerste wel ingevulde maand de maand van afstuderen of de eerste maand ná het afstuderen is, dan worden de eerste maanden van de kalender gevuld met "scholier/student".

5. Afronding cleaning: tot slot van de cleaning worden de cases die niet bruikbaar zijn uit het bestand verwijderd. Dit zijn onder andere de cases die onverwerkbaar zijn doordat vitale informatie ontbreekt en de cases die niet tot de doelgroep behoren (met name schoolverlaters die in een ander jaar de opleiding hebben verlaten).

In principe is het bestand na de cleaning klaar voor gebruik. Om de bruikbaarheid ervan echter te vergemakkelijken wordt er tevens een aantal nieuwe variabelen aan het bestand toegevoegd. Veelal zijn dit variabelen die veelvuldig afgeleid zouden moeten worden voor de analyses. Zo is bijvoorbeeld voor de variabele 'beroepsbevolking' de antwoorden op meer dan vijf vragen nodig.

\section{Weging}

De deelname van de scholen aan de schoolverlatersonderzoeken geschiedt, zoals vermeld in paragraaf 2, op vrijwillige basis. Hierdoor ontstaat er in de regel een ongelijke spreiding naar opleiding en regio. Ook naar andere kenmerken van de populatie kan er een scheefheid in de verdeling ontstaan. Zo is de respons bij vrouwen in het algemeen hoger dan bij mannen, waardoor vrouwen oververtegenwoordigd zijn in het onderzoeksbestand. Dergelijke ongelijkheden leiden ertoe dat het onderzoeksbestand geen landelijke representatie is van de doelgroep. Om toch betrouwbare landelijke gegevens te kunnen presenteren, wordt een weging uitgevoerd op het bestand zoals dat na de dataverwerking is verkregen. Daarbij wordt een zodanige weging uitgevoerd dat de aantallen corresponderen met de aantallen in de populatie (ophoging). Voor de weging wordt gebruik gemaakt van de populatiegegevens die beschikbaar zijn op basis van de Integrale Leerlingtelling (ILT), voor wat betreft het voortgezet onderwijs en het (kort) MBO, en het Centraal Register Instellingen Hoger Onderwijs (CRIHO), voor wat betreft het HBO. Beide databestanden worden beheerd door het Ministerie van Onderwijs, Cultuur en Wetenschappen.Ten aanzien van de schoolverlaters van de landbouwopleidingen wordt gebruik gemaakt van door het Ministerie van Landbouw, Natuurbeheer en Visserij beschikbaar gestelde gegevens.

Tabel 3.1

Aantallen schoolverlaters per opleidingssector in het ongewogen en gewogen bestand, 1997 


AVO
MAVO
HAVO
VWO
VBO
IVBO
landbouw
techniek
economie
gezondheidszorg
BOL niveau 1/2
oriënteren en schakelen
landbouw
techniek
economie
gezondheidszorg

$V B O$

\title{
BOL niveau 3/4
}

landbouw

21.500

150

9.100

277

800

554

3.000

216

6.500

2.000

techniek

7.491

984

55.700

1.735

3.700

2.163

13.600

economie

gezondheidszorg

1.565

21.200

gedrag en maatschappij

1.044

9.000

8.000

\author{
HBO voltijd \\ landbouw \\ onderwijs \\ economie \\ gezondheidszorg \\ gedrag en maatschappij \\ kunst en cultuur
HBO deeltijd
landbouw
onderwijs
techniek
economie
gezondheidszorg
gedrag en maatschappij
kunst en cultuur

14.737

1.152

2.169

3.082

4.310

1.192

1.578

1.254

42.500

2.100

6.800

11.100

11.700

3.600

2.436

4.600

2.800

$\begin{array}{rr}.436 & 9.200 \\ 12 & 100 \\ 682 & 3.200 \\ 140 & 500 \\ 334 & 1.300 \\ 319 & 1.400 \\ 788 & 2.500 \\ 161 & 300\end{array}$

$W O^{a}$

2.975

a. Bij het WO heeft geen weging plaatsgevonden (wegingsfactor 1), zodat de gewogen aantallen gelijk zijn aan de ongewogen aantallen.

In de ILT 1995/1996 zijn per instelling en per opleiding gegevens beschikbaar over het aantal 
leerlingen per leerjaar en geslacht ${ }^{7}$. Het CRIHO bevat per instelling en opleiding gegevens over het aantal diploma's, waarbij eveneens een onderverdeling naar geslacht is gemaakt. Bovendien wordt bij de opleidingen een onderscheid gemaakt tussen de voltijd- en de deeltijdopleidingen. Aangezien met name de ILT op sommige punten afwijkt van de officiële statistieken zijn de uiteindelijke resultaten geschaald naar de Onderwijsmatrix. Helaas zijn deze laatste gegevens onvoldoende gedetailleerd om als uitgangspunt te dienen bij de ophoging.

In principe wordt op het niveau van opleiding $x$ voltijd/deeltijd (alleen HBO) $x$ regio $x$ geslacht een wegingsfactor bepaald als het quotiënt van het aantal in de populatie en het aantal in het onderzoeksbestand. Indien echter de resulterende weegfactor groter is dan 3 maal de gemiddelde weegfactor en bovendien het aantal cases dat wordt gewogen kleiner is dan 50 , dan wordt eerst de dimensie geslacht en indien noodzakelijk ook de dimensie regio buiten beschouwing gelaten. In dat geval wordt derhalve gewogen op het niveau van opleiding $x$ voltijd/deeltijd (alleen HBO) $x$ regio, respectievelijk opleiding $x$ voltijd/deeltijd (alleen HBO). Voor een aantal opleidingen heeft voorafgaand aan de weging een clustering plaatsgevonden. Op dit hogere clusterniveau wordt vervolgens de weging uitgevoerd. Overigens worden in de regel in de schoolverlatersonderzoeken geen landelijke gegevens gepresenteerd wanneer deze betrekking hebben op minder dan 15 respondenten. Tabel 3.1 geeft een overzicht van de aantallen schoolverlaters per opleidingssector vóór en ná de weging. Bij het $\mathrm{HBO}$ is daarbij tevens een onderscheid gemaakt naar voltijd en deeltijd.

\section{Dekkingsgraad en respons}

De schoolverlaters die uiteindelijk in het onderzoeksbestand zijn opgenomen, vormen slechts een gedeelte van de gehele onderzoekspopulatie. Enerzijds worden niet álle personen uit de doelgroep benaderd en anderzijds reageert niet iedereen die wél is benaderd. De dekkingsgraad geeft een beeld van de omvang van het gedeelte van de populatie dat benaderd is. Het responspercentage geeft vervolgens aan welk deel van degenen die benaderd zijn daadwerkelijk gereageerd heeft.

\section{Dekkingsgraad}

Tabel 4.1 laat voor 1997 zien hoe groot de dekkingsgraad per schooltype is ${ }^{8}$. De tabel laat zien dat er tussen de verschillende schooltypen een groot verschil in dekkingsgraad bestaat. Vooral bij het HBO is sprake van een zeer hoge deelname, waardoor een dekking van maar liefst

7. Helaas zijn gegevens over het aantal gediplomeerden met ingang van vorig jaar vanwege privacyredenen niet meer beschikbaar gesteld. Om toch rekening te houden met het rendement van het laatste leerjaar is hiervoor gebruikt gemaakt van gegevens van het voorgaande jaar. Naar verwachting zullen de rendementscijfers in één jaar niet aan hevige veranderingen onderhevig zijn.

8. Het WO is hier buiten beschouwing gelaten. 
$85 \%$ wordt bereikt. Dit is een forse stijging ten opzichte van vorig jaar toen $60 \%$ van de afgestudeerden werd benaderd. Ook voor het BOL niveau $1 / 2$ en niveau $3 / 4$ is de dekkingsgraad gestegen ten opzichte van vorig jaar. Dit jaar is respectievelijk $41 \%$ en $32 \%$ van alle schoolverlaters van deze opleidingssectoren benaderd om deel te nemen aan de enquête. $\mathrm{Bij}$ het AVO en VBO is de dekkingsgraad licht gedaald. Hier ligt de dekkingsgraad ook aanzienlijk lager dan bij de overige opleidingstypen. Bij deze schooltypen is zo'n $5-10 \%$ van de schoolverlaters benaderd.

Tabel 4.1

Dekkingsgraad per schooltype, 1997

\begin{tabular}{lcc} 
Schooltype & $\begin{array}{c}\text { Benaderd } \\
\text { aantal }\end{array}$ & $\begin{array}{c}\text { Dekking } \\
\%\end{array}$ \\
\hline & & \\
AVO & 7.348 & 8 \\
VBO & 4.595 & 41 \\
BOL niveau 1/2 & 4.938 & 32 \\
BOL niveau 3/4 & 18.483 & 85 \\
HBO & 36.285 &
\end{tabular}

\section{Respons}

De respons ${ }^{9}$ is met $53 \%$ het hoogste bij de schoolverlaters van het $A V O$, het $\mathrm{HBO}$ deeltijd en het WO, zoals blijkt uit tabel 4.2. Bij het BOL niveau $1 / 2$ is helaas sprake van een vrij lage respons: $32 \%$. BOL niveau $3 / 4$ en het $\mathrm{HBO}$ voltijd kennen responspercentages van iets minder dan $50 \%$. De respons is over de gehele linie gedaald ten opzichte van vorig jaar. De daling is het grootst bij het AVO en het VBO. Voor beide opleidingstypen valt een responsafname van meer dan 10\%-punten te constateren. Middels een responsanalyse wordt getracht een beter inzicht te krijgen in de oorzaken van de aanzienlijke daling van het responspercentage. Aangezien er (per definitie) vrij weinig gegevens bekend zijn over de schoolverlaters die niet gerespondeerd hebben, is de responsanalyse noodzakelijkerwijs beperkt. Drie factoren die mogelijk invloed hebben op de respons en die bekend zijn, zijn: ten eerste de wijze van verzending van de vragenlijsten. De vragenlijsten kunnen enerzijds centraal door DESAN aan de individuele schoolverlater worden toegestuurd, anderzijds kunnen de individuele onderwijsinstellingen de vragenlijsten ook zelf verzenden. Dit laatste noemen we decentrale verzending. Ten tweede de regioverdeling in de steekproef. Wellicht geldt dat het responspercentage in de ene regio hoger ligt dan in de andere.

Tabel 4.2

Responspercentage per opleidingssector, 1997

9. Voor de berekeningswijze van de respons, zie Willems en Van der Linden (1998). 


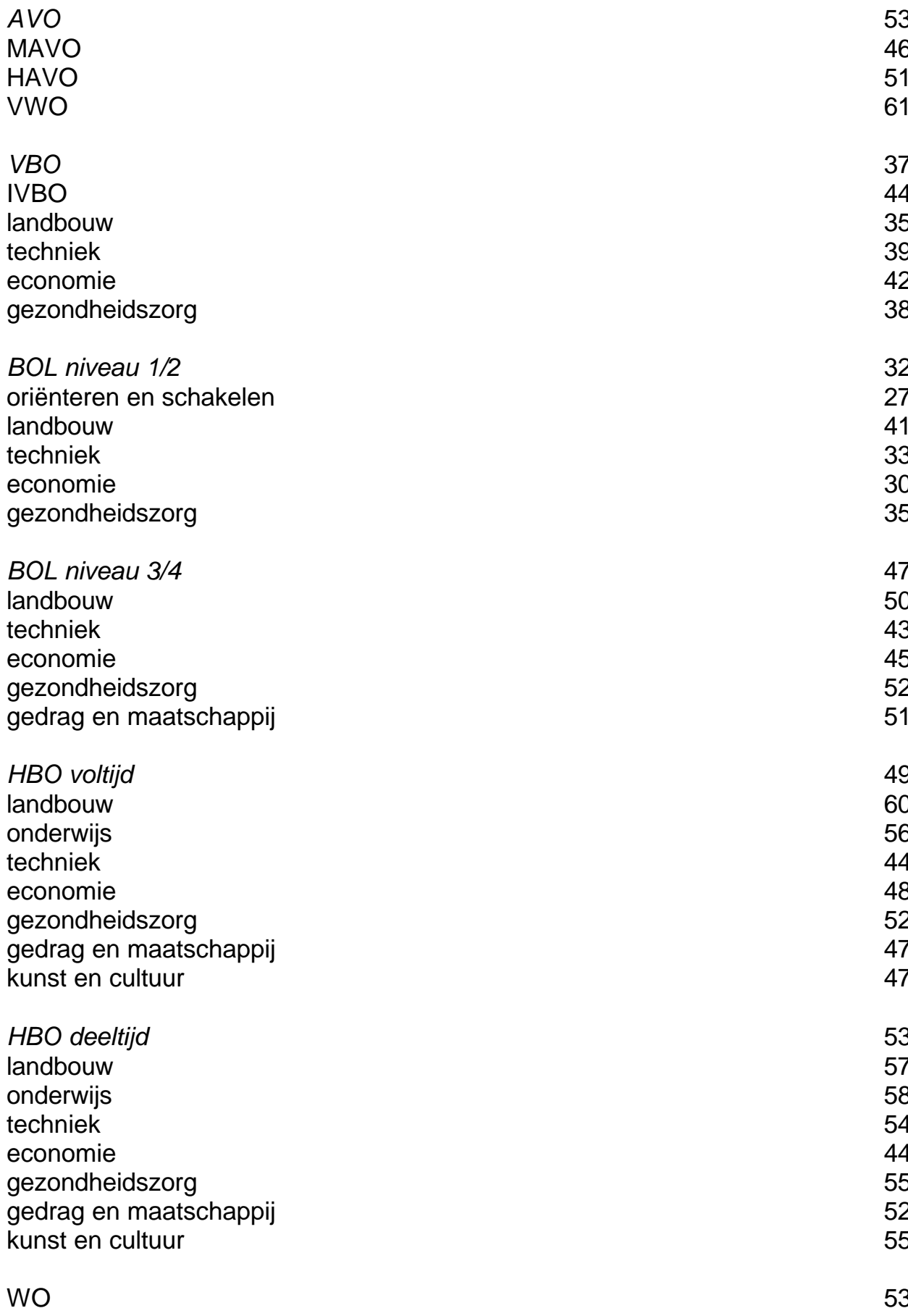

Wanneer nu een bepaalde regio in de loop der jaren een steeds belangrijkere rol is gaan vervullen in de steekproef en de responspercentages tussen regio's inderdaad verschillen dan kan dit een verklaring zijn voor veranderingen in de respons. Dit laatste kan natuurlijk ook 
gelden voor opleidingsniveau. Deze drie factoren zijn in een logistische regressie opgenomen om het bepalen wat hun effect is op de respons. Dit staat weergegeven in tabel 4.3

Tabel 4.3

De kans op respons bepaald door, het opleidingsniveau, de wijze van verzending en regionale verschillen

Onafhankelijke factoren Parameter $\quad$ Standaardfout

\begin{tabular}{lll} 
constante & $-0,03$ & 0,02 \\
Opleidingsniveau: & & \\
AVO & $0,36^{* *}$ & 0,03 \\
VBO & $-0,35^{\star *}$ & 0,04 \\
BOL 1/2 & $-0,59^{\star *}$ & 0,04 \\
BOL 3/4 & $0,04^{*}$ & 0,02 \\
HBO & referentiecategorie & \\
Regio: & & \\
noord & $-0,08^{\star *}$ & 0,03 \\
oost & $-0,02$ & 0,03 \\
west & $-0,22^{\star *}$ & 0,02 \\
zuid & referentiecategorie & \\
& & \\
decentrale verzending & $-0,04$ & 0,02 \\
N $=63.295$ & & \\
\hline
\end{tabular}

* $5 \%$-significantie niveau

** $1 \%$-significantie niveau

De analyse toont dat, gecorrigeerd voor regio en wijze van verzending, schoolverlaters van het AVO het vaakst responderen, gevolgd door schoolverlaters van BOL niveau 3/4. Zoals tabel 4.2 reeds heeft laten zien, is de respons onder de schoolverlaters van BOL niveau $1 / 2$ relatief laag. Verder blijkt dat de respons geografisch scheef verdeeld is. De respons is met name laag in de regio's west en noord. Daarnaast blijkt dat decentrale verzending van de vragenlijsten een iets lagere respons oplevert dan wanneer de vragenlijsten centraal worden verzonden, alhoewel het verschil niet significant is. Wellicht spelen hier twee tegengestelde effecten een rol. Aan de ene kant is de respons bij sommige zelfverzendende instellingen hoger, omdat de schoolverlaters nog een band hebben met hun voormalige school. Aan de andere kant zijn er echter ook zelfverzendende onderwijsinstellingen waar de respons aanzienlijk lager ligt. De onervarenheid met enquête-onderzoek kan hierbij een rol spelen.

Om te bepalen wat de invloed kan zijn van de opleidings- en regio-verschillen worden de opleidings- en regio-aandelen in de databestanden van 1997 en 1996 vergeleken. Tabel 4.4 geeft de opleidingsaandelen van beide bestanden. Het blijkt dat er in 1997 relatief gezien minder HBO-afgestudeerden deelnamen dan in 1996, hiervoor in de plaats zijn er relatief meer VBO-schoolverlaters geënquêteerd. Aangezien HBO'ers gemiddeld genomen vaker responderen $(46 \%)$ dan VBO-schoolverlaters (37\%) wordt hierdoor de gemiddelde respons lager. De 
verschillen die optreden als gevolg van de lichte verschuivingen van de aandelen van opleidingstypen zijn echter dermate klein dat ze de responsdaling niet kunnen verklaren.

Tabel 4.4

Effecten van veranderingen in de opleidingsaandelen op de respons

\begin{tabular}{|c|c|c|c|c|c|}
\hline $\begin{array}{c}\text { Opleidings- } \\
\text { niveau } \\
\%\end{array}$ & $\begin{array}{c}\text { Respons } \\
\text { kans } \\
\%\end{array}$ & $\begin{array}{c}\text { Aandeel } 1996 \\
\%\end{array}$ & $\begin{array}{l}\text { Aandeel } 1997 \\
\text { \%-punten }\end{array}$ & $\begin{array}{l}\text { Verschil aandeel } \\
1997-1996 \\
\% \text {-punten }\end{array}$ & $\begin{array}{l}\text { Respons } \\
\text { effect }\end{array}$ \\
\hline $\begin{array}{l}\text { AVO } \\
\text { VBO } \\
\text { BO niveau } 1 / 2 \\
\text { BO niveau } 3 / 4 \\
\text { HBO }\end{array}$ & $\begin{array}{l}54 \\
37 \\
32 \\
47 \\
46\end{array}$ & $\begin{array}{r}9,6 \\
3,4 \\
4,8 \\
23,7 \\
58,4\end{array}$ & $\begin{array}{r}10,7 \\
6,1 \\
4,3 \\
22,8 \\
56,1\end{array}$ & $\begin{array}{l}1,1 \\
2,7 \\
0,5 \\
0,9 \\
2,3\end{array}$ & $\begin{array}{r}0,59 \\
1,00 \\
-0,16 \\
-0,42 \\
-1,06\end{array}$ \\
\hline totaal & $46^{\mathrm{a}}$ & 100,0 & 100,0 & 0,0 & $-0,05$ \\
\hline
\end{tabular}

\footnotetext{
${ }^{a}$ Het hier gepresenteerde responspercentage komt niet overeen met het percentage dat in de schoolverlatersrapportages wordt gepresenteerd. Dit verschil wordt veroorzaakt doordat de telefonische respons in de schoolverlatersrapportages als respons worden meegenomen, terwijl ze in deze methodiek als non-respons worden aangemerkt. Immers, de schoolverlaters die telefonisch worden benaderd zijn in een eerder stadium ook schriftelijk benaderd maar hebben toen niet gereageerd.
}

Wat betreft de regioverdeling is het aandeel van de regio west in 1997 aanmerkelijk gegroeid ten opzichte van 1996. Dit is ten koste gegaan van voornamelijk de regio oost, zoals blijkt uit tabel 4.5. Aangezien de regio west een lagere respons heeft dan de regio oost zal dit een negatief effect hebben op de totale respons. Het blijkt dat de veranderingen in de regioaandelen de totale respons met 0,21\%-punten doet dalen. Tezamen zijn beide factoren verantwoordelijk voor een daling van iets minder dan $0,3 \%$ van de respons. Aangezien de respons in totaal ten opzichte van 1996 met ruim $11 \%$ is gedaald, kan dus slechts een fractie van deze daling verklaard worden door de populatieverschillen opleiding en regio zoals die beschreven zijn.

Tabel 4.6 geeft tot slot een overzicht van de in 1997 uitgezette en (niet) terug ontvangen vragenlijsten. Dit overzicht geeft de belangrijkste traceerbare reden van non-respons weer. De belangrijkste is het ontbreken van een actueel adres. Voor ruim $4 \%$ van de aangeschrevenen is dit het geval.

Tabel 4.5

Effecten van veranderingen in regio-aandelen op de respons

\begin{tabular}{|c|c|c|c|c|c|}
\hline Regio & $\begin{array}{l}\text { Respons } \\
\text { kans } \\
\%\end{array}$ & Aandeel 1996 & $\begin{array}{c}\text { Aandeel } 1997 \\
\%\end{array}$ & $\begin{array}{l}\text { Verschil aandeel } \\
1997-1996 \\
\% \text {-punten }\end{array}$ & $\begin{array}{l}\text { Respons- } \\
\text { effect } \\
\% \text {-punten }\end{array}$ \\
\hline
\end{tabular}




\begin{tabular}{lrrrrr}
\hline noord & & & & & \\
oost & 47 & 10,3 & 9,0 & $-1,3$ & $-0,61$ \\
west & 48 & 19,6 & 14,6 & $-5,0$ & $-2,40$ \\
zuid & 44 & 48,2 & 52,6 & 4,4 & 1,94 \\
totaal & 48 & 22,0 & 23,8 & 1,8 & 0,86 \\
& 46 & 100,0 & 100,0 & 0,0 & $-0,21$ \\
\hline
\end{tabular}

Tabel 4.6

Resultaat dataverzameling in aantallen per schooltype

AVO VBO BOL1/2 BOL 3/4 HBO WO Totaal

Totaal uitgezet

$\begin{array}{lllllll}7.348 & 4.595 & 4.938 & 18.483 & 36.285 & 5.777 & 77.426\end{array}$

Retour ontvangen, beschikbaar voor verwerking

$\begin{array}{lllllll}3.915 & 1.826 & 1.486 & 7.837 & 18.009 & 3.076 & 36.149\end{array}$

Retour ontvangen, niet geschikt voor verwerking, vanwege

- onbestelbaar retour

- weigering: anonimiteit of andere reden

- onverwerkbaar

- school-/studiejaar verkeerd

- overige redenen

$\begin{array}{rrrrrrr}155 & 181 & 238 & 739 & 1.744 & 235 & 3.292 \\ 4 & 26 & 21 & 59 & 68 & 3 & 181 \\ 59 & 126 & 95 & 135 & 34 & 2 & 451 \\ 71 & 101 & 53 & 210 & 713 & 73 & 1.221 \\ 120 & 24 & 172 & 583 & 239 & 35 & 1.173\end{array}$

\section{Non-respons}

Zoals in paragraaf 4 is aangegeven, varieert de respons van het schoolverlatersonderzoek van $32 \%$ voor het kort MBO tot $53 \%$ voor het AVO, HBO deeltijd en het WO. De resultaten zoals die beschreven staan in de landelijke en instellingsrapportages zijn vanzelfsprekend gebaseerd op deze responsgroep. Om te achterhalen of de onderzoeksresultaten die verkregen worden door gebruik te maken van de gegevens van deze responsgroep geen vertekening van de werkelijkheid vormen, is het belangrijk om te weten of er sprake is van een selectieve respons. Stel bijvoorbeeld dat de schoolverlaters die werkloos zijn in grote getale weigeren aan de enquête deel te nemen. Het werkloosheidspercentage dat berekend wordt met behulp van de gegevens van de responsgroep laat in dat geval een onderschatting van het werkelijke werkloosheidspercentage zien.

Eventuele selectiviteit van de respons kan worden nagegaan door op enkele belangrijke kenmerken de responsgroep met de non-responsgroep te vergelijken. Dit is in principe op twee manieren mogelijk: (1) door de kenmerken van de responsgroep te vergelijken met de kenmerken van de doelgroeppopulatie die reeds op basis van andere bronnen bekend zijn of (2) door een aanvullend onderzoek te houden onder de non-responsgroep, waarbij over enkele 
kernvariabelen informatie wordt ingewonnen. Ten aanzien van het schoolverlatersonderzoek is vooraf nauwelijks enige informatie bekend, behoudens gevolgde opleiding, geslacht en regio. Aangezien deze gegevens echter reeds gebruikt worden om het onderzoekbestand te herwegen - waardoor op deze punten een landelijk representatief beeld ontstaat - is voor het nagaan van de representativiteit ten aanzien van enkele kernvariabelen derhalve een nonresponsonderzoek noodzakelijk.

De vraag is vervolgens over welke kenmerken van de non-responsgroep informatie verzameld dient te worden. Het antwoord wordt bepaald door het belang dat binnen het schoolverlatersonderzoek aan de verschillende kenmerken wordt gehecht en de mate waarin verwacht mag worden dat de respons op deze punten selectief is. De bestemming oftewel de maatschappelijke positie van schoolverlaters na het verlaten van de opleiding kan beschouwd worden als één van de belangrijkste kernpunten in de schoolverlatersenquêtes. Bovendien zou juist op dit punt selectiviteit in de respons kunnen ontstaan. Evenals in voorgaande jaren is het nonresponsonderzoek voor het uitvoeringsjaar 1997 daarom vooral toegespitst op de bestemming van schoolverlaters.

Een ander belangrijk aspect binnen het schoolverlatersonderzoek omvat het onderzoek onder degenen die betaald werk verrichten. Daarom wordt in het non-responsonderzoek ook getoetst op eventuele selectiviteit in de antwoorden op de vraag "Heb je op dit moment (ook) betaald werk? (inclusief een betaalde bijbaan en/of een leer-arbeidsplaats)". Behalve het bestaan van eventuele selectiviteit tussen de respondenten en de non-respondenten ten aanzien van de twee genoemde variabelen bestemming en betaald werk, wordt er vanuit gegaan dat er geen selectiviteit is opgetreden ten aanzien van de overige variabelen in de vragenlijst. Zo is er bijvoorbeeld geen grond om aan te nemen dat degenen die naar een technische vervolgopleiding zijn gegaan vaker of minder vaak reageren dan degenen die een economische vervolgopleiding zijn gaan volgen of dat degenen die van beroep timmerman zijn vaker of minder vaak responderen dan degenen die elektricien van beroep zijn.

\section{Non-responsonderzoek}

Het non-responsonderzoek voor 1997 heeft evenals in afgelopen jaren plaatsgevonden aan de hand van een korte telefonische enquête. Deze is gehouden onder een steekproef van degenen die in eerste instantie de schriftelijke vragenlijst niet hebben geretourneerd. De opleidingssector HBO kunst en cultuur en HBO onderwijs vormt een uitzondering op de steekproeftrekking: hiervan zijn de non-respondenten, zoals eerder is aangegeven, integraal telefonisch benaderd.

De steekproef van het non-responsonderzoek is gestratificeerd naar schooltype. Binnen een schooltype wordt aselect getrokken over de verschillende opleidingssectoren. Achteraf bleek echter de sector landbouw in alle opleidingstypen en met name binnen het VBO sterk oververtegenwoordigd te zijn in het non-responsonderzoek. Dit heeft te maken met enerzijds de vrijwel integrale deelname van deze sector aan het schoolverlatersonderzoek en anderzijds de relatief 
lage respons, waardoor een oververtegenwoordiging in de non-responsgroep ontstaat.

Voor het uitvoeren van het telefonisch onderzoek onder de non-respondenten is - naast de lijst die voor het kunst- en het pedagogisch onderwijs is gebruikt - gebruik gemaakt van een tweetal verschillende vragenlijsten: één voor schoolverlaters van AVO/VBO/BOL/BBL en één voor die van het $\mathrm{HBO}$. Aan de hand van die lijsten is onder andere informatie verzameld over de gevolgde opleiding van de non-respondent, de belangrijkste bezigheid op het moment van enquêteren en (indien van toepassing) over de huidige baan. Aan alle non-respondenten is tevens gevraagd naar de reden waarom men in eerste instantie niet heeft deelgenomen aan het onderzoek.

Tabel 5.1 laat per schooltype zien wat de redenen van weigering door de non-respondenten zijn geweest. Hierbij gaat het dus om de non-respondenten die in eerste instantie niet hebben deelgenomen aan het onderzoek, maar wel aan de telefonische enquête. De belangrijkste reden waarom schoolverlaters de vragenlijst niet hebben ingevuld en teruggestuurd is dat het invullen teveel tijd of moeite kost. Daarnaast geven vooral AVO'ers aan dat zij zijn vergeten de vragenlijst in te vullen en/of terug te sturen. Bij schoolverlaters van het BOL niveau 1/2 vormt ook geen interesse een belangrijk motief voor het niet invullen van de vragenlijst. Overigens moet worden bedacht dat er bij het telefonisch benaderen van de non-respondenten wederom non-respons optreedt. De belangrijkste reden voor deze 'tweede non-respons' is dat de schoolverlaters zijn verhuisd of dat het telefoonnummer verkeerd is. Expliciet wordt opgemerkt dat bij het telefonisch non-respons onderzoek er naar is gestreefd om uit een zo klein mogelijke groep een vast aantal schoolverlaters te benaderen. In totaal zijn 3.002 mensen benaderd voor 1.482 geslaagde gesprekken.

\section{Toets op selectiviteit}

Vervolgens kan worden nagegaan of de responsgroep en de groep die aanvankelijk niet op de schriftelijke enquête heeft gereageerd op de eerder genoemde kernvariabelen bestemming en betaald werk - van elkaar verschillen. De significantie van dit verschil kan worden bepaald aan de hand van de toets van Fisher (zie bijvoorbeeld Van der Genugten, 1986, blz. 298-304). Voordat deze Fisher-toets kan worden toegepast, is het echter noodzakelijk om eerst enkele aanpassingen in de databestanden van zowel de nonresponsgroep als de responsgroep door te voeren. Ten eerste zijn de afgestudeerden van het kunstonderwijs en het hoger pedagogisch onderwijs die telefonisch gereageerd hebben bij de respons toegevoegd aan de non-respons in plaats van, als bij de landelijke rapportages, de respons.

Tabel 5.1

Redenen van schoolverlaters om in eerste instantie niet deel te nemen aan het onderzoek in percentages per schooltype

Reden

$\begin{array}{cccccc}\text { AVO } & \text { VBO } & \text { BOL 1/2 } & \text { BOL 3/4 } & \text { HBO } & \text { Totaal } \\ \% & \% & \% & \% & \% & \%\end{array}$


Geen echte reden

Vragenlijst nooit ontvangen

Vragenlijst kwijtgeraakt

Vergeten

Geen interesse

Invullen kost teveel tijd/moeite

Bedenkingen bij anonimiteit en/of privacy

Vragenlijst was niet op mij van toepassing 4

lets anders

$\begin{array}{rrrrrr}10 & 11 & 14 & 2 & 9 & 9 \\ 9 & 8 & 12 & 12 & 11 & 10 \\ 5 & 4 & 0 & 4 & 4 & 4 \\ 22 & 11 & 10 & 15 & 14 & 14 \\ 11 & 13 & 20 & 15 & 11 & 13 \\ 28 & 38 & 24 & 32 & 33 & 31 \\ 2 & 0 & 0 & 2 & 2 & 2 \\ 4 & 2 & 7 & 9 & 3 & 4 \\ 10 & 12 & 12 & 9 & 14 & 13\end{array}$

Verder is de verdeling naar opleidingssector verschillend tussen het responsbestand en het non-responsbestand. Om hiervoor te corrigeren - en dus beide bestanden op dit punt vergelijkbaar te maken - is ten tweede het responsbestand zodanig (opnieuw) gewogen dat de verdeling over de opleidingssectoren overeenkomt met die van het non-responsbestand ${ }^{10}$. Tabel 5.2 laat per schooltype voor elke bestemmingscategorie het resultaat van de toets van Fisher zien. Voor de volledigheid is aangegeven hoe de bestemming van de non-responsgroep en de responsgroep er in aantallen en percentages uit ziet. De aantallen voor de responsgroep zijn daarbij, zoals gezegd, zodanig aangepast dat de verdeling van de schoolverlaters over de opleidingssectoren binnen het desbetreffende schooltype gelijk is aan de verdeling binnen dat schooltype in het non-responsbestand ${ }^{11}$. De aantallen in de twee kolommen vormen de basis voor het berekenen van de z-score. Voor de meeste opleidingssectoren geldt dat de personen in het non-respons bestand vaker werkloos zijn dan de personen in het respons bestand, alhoewel het verschil alleen voor het AVO en het BOL niveau 3/4 significant is. Dit betekent dat het percentage schoolverlaters dat zichzelf werkloos vindt, op basis van het gebruikte onderzoeksbestand onderschat zou worden. Verder geven schoolverlaters van het BOL niveau 1/2, die aan het non-respons onderzoek hebben meegewerkt, aan vaker te zijn doorgestroomd naar het leerlingwezen dan schoolverlaters van BOL niveau 1/2 die aan de reguliere enquête hebben meegedaan.

Tabel 5.2

Toets van Fisher op selectiviteit naar bestemming tussen respondenten en non-respondenten per schooltype

Bestemming

Non-respons ${ }^{\mathrm{a}}$ aantal \%

Respons $^{\mathrm{b}, \mathrm{c}}$

Z-score

aantal \%

AVO

Ilw/in-service

33

53

4

$-0,46$

10. In principe zou het ook mogelijk zijn geweest om het non-responsbestand te herwegen naar het (al dan niet gewogen) responsbestand. Aangezien echter het non-responsbestand sterk scheef verdeeld is over de opleidingssectoren, zou dit leiden tot zeer hoge en dus onbetrouwbare weegfactoren.

11. Uiteraard zou men de verdelingen nog meer op elkaar kunnen afstemmen door bijvoorbeeld ook rekening te houden met het geslacht. Dit is echter niet gedaan omdat de aantallen in het nonresponsbestand daarvoor te klein zijn. 


\begin{tabular}{|c|c|c|c|c|c|}
\hline betaald werk & 11 & 11 & 128 & 9 & 0,51 \\
\hline studie & 84 & 82 & 1.188 & 86 & $-0,99$ \\
\hline werkloos & 3 & 3 & 6 & 0 & $3,15^{\star}$ \\
\hline anders & 1 & 1 & 8 & 1 & 0,50 \\
\hline \multicolumn{6}{|l|}{$V B O$} \\
\hline Ilw/in-service & 21 & 21 & 214 & 17 & 1,01 \\
\hline betaald werk & 26 & 26 & 388 & 31 & $-1,02$ \\
\hline studie & 50 & 50 & 613 & 49 & 0,23 \\
\hline werkloos & 2 & 2 & 22 & 2 & 0,18 \\
\hline anders & 1 & 1 & 19 & 2 & $-0,41$ \\
\hline \multicolumn{6}{|l|}{ BOL niveau $1 / 2$} \\
\hline \|w/in-service & 18 & 18 & 147 & 11 & $2,09^{*}$ \\
\hline betaald werk & 58 & 57 & 870 & 65 & $-1,52$ \\
\hline studie & 16 & 16 & 239 & 18 & $-0,51$ \\
\hline werkloos & 8 & 8 & 72 & 5 & 1,08 \\
\hline anders & 1 & 1 & 12 & 1 & 0,10 \\
\hline \multicolumn{6}{|l|}{$B O L$ niveau 3/4 } \\
\hline Ilw/in-service & 8 & 8 & 52 & 4 & 1,90 \\
\hline betaald werk & 61 & 60 & 874 & 67 & $-1,25$ \\
\hline studie & 27 & 27 & 366 & 28 & $-0,24$ \\
\hline werkloos & 5 & 5 & 17 & 1 & $2,86^{*}$ \\
\hline anders & 0 & 0 & 5 & 0 & $-0,62$ \\
\hline \multicolumn{6}{|l|}{$\mathrm{HBO}$} \\
\hline betaald werk & 1.547 & 86 & 20.504 & 85 & 0,76 \\
\hline studie & 117 & 6 & 1.911 & 8 & $-2,20^{*}$ \\
\hline werkloos & 75 & 4 & 1.002 & 4 & $-0,00$ \\
\hline anders & 63 & 3 & 651 & 3 & $1,98^{*}$ \\
\hline
\end{tabular}

a. Inclusief telefonische respons (kunst- en pedagogisch onderwijs).

b. Exclusief telefonische respons (kunst- en pedagogisch onderwijs).

c. Gewogen naar de verdeling over de opleidingssectoren in het non-responsbestand. De hier gepresenteerde aantallen wijken derhalve af van de in de (landelijke) rapportages genoemde aantallen.

* Significant op 5\%-niveau

Of er sprake is van selectiviteit tussen de respons en de non-responsgroep in de antwoorden op de vraag 'Heb je op dit moment (ook) betaald werk? (inclusief een betaalde bijbaan en/of een leer-arbeidsplaats)' is weergegeven in tabel 5.3.

Tabel 5.3

Toets van Fisher op selectiviteit in het aandeel betaald werkende respondenten en het aandeel betaald werkende non-respondenten per schooltype

$\begin{array}{llll}\text { Betaald werk } & \begin{array}{c}\text { Non-respons } \\ \text { aantal } \%\end{array} & \begin{array}{l}\text { Respons } \\ \text { aantal }\end{array}\end{array} \quad$ Z-score

$\begin{array}{llllll}V B O & & & & & \\ \text { ja } & 70 & 69 & 725 & 56 & 2,40^{*} \\ \text { nee } & 32 & 31 & 561 & 44 & \end{array}$


BOL niveau $1 / 2$

ja $\begin{array}{llll}77 & 74 & 880 & 65\end{array}$

nee

$27 \quad 26$

$484 \quad 36$

BOL niveau 3/4

ja

$\begin{array}{llll}79 & 78 & 1.016 & 77\end{array}$

$\begin{array}{llll}22 & 22 & 309 & 23\end{array}$

nee

1.67590

21.444

88

$2.908 \quad 12$

ja

$177 \quad 10$

a. Inclusief telefonische respons (kunst- en pedagogisch onderwijs).

b. Exclusief telefonische respons (kunst- en pedagogisch onderwijs).

c. Gewogen naar de verdeling over de opleidingssectoren in het non-responsbestand. De hier gepresenteerde aantallen wijken derhalve af van de in de (landelijke) rapportages genoemde aantallen.

* Significant op 5\%-niveau

$\mathrm{Bij}$ alle schooltypen, is de fractie betaald werkenden onder de non-respondenten iets groter dan onder de respondenten. $\mathrm{Bij}$ het $\mathrm{VBO}, \mathrm{KMBO}$ en het $\mathrm{HBO}$ is er overigens sprake van een significant verschil tussen de respons- en de non-responsgroep. De non-responsgroep bevat relatief gezien meer betaald werkenden dan de responsgroep.

\section{Consequentie van non-respons}

De vraag is vervolgens wat de consequentie van deze enigszins selectieve non-respons is. Om hiervan een beeld te krijgen, onderzoeken we het 'maximale' effect van de non-respons op de resultaten. Daarvoor wordt verondersteld dat het uitgevoerde non-respons onderzoek (na weging) representatief is voor alle non-respondenten. Samenvoeging van de gegevens van de responsgroep en de non-respons groep - aangeduid als het gecombineerde bestand geeft vervolgens een beeld van de verschillen. In tabel 5.4 staat voor zowel de feitelijke respons als het genoemde gecombineerde bestand de bestemming van schoolverlaters naar opleidingsniveau weergegeven, berekend aan de hand van de zojuist voorgestelde methoden $^{12}$.

Tabel 5.4

Bestemming van schoolverlaters volgens het gecombineerde bestand en het gewogen respons bestand

\begin{tabular}{|c|c|c|c|c|c|c|c|c|c|c|}
\hline & \multicolumn{2}{|c|}{ AVO } & \multicolumn{2}{|c|}{ VBO } & \multicolumn{2}{|c|}{ BO 1/2 } & \multicolumn{2}{|c|}{ BO $3 / 4$} & \multicolumn{2}{|c|}{$\mathrm{HBO}$} \\
\hline & $\begin{array}{l}A \\
\%\end{array}$ & $\begin{array}{l}\text { B } \\
\%\end{array}$ & $\begin{array}{l}A \\
\%\end{array}$ & $\begin{array}{l}\text { B } \\
\%\end{array}$ & $\begin{array}{l}A \\
\%\end{array}$ & $\begin{array}{l}\text { B } \\
\%\end{array}$ & $\begin{array}{l}\text { A } \\
\%\end{array}$ & $\begin{array}{l}\text { B } \\
\%\end{array}$ & $\begin{array}{l}\text { A } \\
\%\end{array}$ & $\begin{array}{l}B \\
\%\end{array}$ \\
\hline leerlingwezen & 3 & 4 & 19 & 18 & $16^{*}$ & 9 & 6 & 4 & - & - \\
\hline
\end{tabular}

12. De hier gepresenteerd cijfers van het gewogen bestand zijn niet vergelijkbaar met cijfers die in de diverse rapportages zijn gepubliceerd, omdat daar andere selecties zijn toegepast (in de rapportages zijn bijvoorbeeld slechts gediplomeerden meegenomen). 


\begin{tabular}{|c|c|c|c|c|c|c|c|c|c|}
\hline $\begin{array}{l}\text { betaald werk } \\
\text { studie }\end{array}$ & $\begin{array}{l}10 \\
86\end{array}$ & $\begin{array}{r}8 \\
87\end{array}$ & $\begin{array}{l}28 \\
50\end{array}$ & $\begin{array}{l}29 \\
51\end{array}$ & $\begin{array}{l}60 \\
17^{*}\end{array}$ & $\begin{array}{l}54 \\
34\end{array}$ & $\begin{array}{l}63 \\
27\end{array}$ & $\begin{array}{l}63 \\
32\end{array}$ & $\begin{array}{r}88 \\
7\end{array}$ \\
\hline werkloos & $1^{*}$ & 0 & 2 & 1 & $7^{*}$ & 3 & $4^{*}$ & 1 & 4 \\
\hline anders & 0 & 1 & 1 & 1 & 1 & 0 & 0 & 0 & 1 \\
\hline
\end{tabular}

*significant op 5\%-niveau

A gecombineerde bestand

B gewogen respons bestand

Er zijn wat betreft de bestemming van schoolverlaters weinig verschillen waar te nemen tussen het gecombineerde bestand en het gewogen respons bestand. Het enige opleidingsniveau waarbij de resultaten tussen beide methoden uiteenlopen is BOL niveau 1/2. Het blijkt dat uitstroom naar het leerlingwezen voor de schoolverlaters van BOL niveau 1/2 op basis van het gewogen respons bestand duidelijk wordt onderschat. Van de respondenten stroomt een groter deel juist vaker door naar een vervolgopleiding.

\section{Besluit}

Dit werkdocument geeft de methodologische verantwoording van het schoolverlatersonderzoek zoals dat door het ROA in 1997 is uitgevoerd. Naast een overzicht van de opzet van dit onderzoek, de gehanteerde classificaties en de uitgevoerde controles en toegepaste correcties op het databestand, is vooral ingegaan op de dekkingsgraad (de 'steekproefomvang') en de respons. Expliciet is ingegaan op de non-respons. Behalve dit werkdocument is er voor gebruikers van het databestand een documentatieklapper beschikbaar.

Uit het gepresenteerde overzicht van dekkingsgraden blijkt dat het schoolverlatersonderzoek erg grootschalig van opzet is. Met name in het HBO is de steekproefomvang erg hoog te noemen. Hierdoor is het mogelijk om op zeer gedetailleerd niveau van opleidingen betrouwbare uitspraken te doen over de arbeidsmarktpositie van afgestudeerden. Ook bij het MBO is de steekproefomvang met zo'n $30-40 \%$ hoog. Bij het voortgezet onderwijs en het VBO is de dekkingsgraad lager (6-8\%).

De respons is het afgelopen jaar aanzienlijk gedaald. Gemiddeld over alle opleidingen bedroeg de respons iets minder dan $50 \%$. Bij het VBO en het BOL niveau 1/2 is de respons rond de $35 \%$. Een belangrijke vraag daarbij is of de respons selectief is. Dit blijkt nauwelijks het geval te zijn, alhoewel werkende schoolverlaters iets minder vaak responderen dan niet werkende schoolverlaters. De algemene conclusie mag echter zijn dat op basis van het uitgevoerde onderzoek een goed en betrouwbaar beeld van de bestemming en arbeidsmarktpositie van schoolverlaters wordt verkregen.

De daling van de respons ten opzichte van 1996 kan niet worden toegeschreven aan veranderde aandelen van bepaalde opleidingsniveaus of bepaalde regio's. Ook uit het uitgevoerde non-responsonderzoek blijkt geen duidelijke reden naar voren te komen waarom 
de respons gedaald is. Geconstateerd moet worden dat hier sprake is van een algemene tendens tot hogere non-respons. Alhoewel deze al enige jaren zichtbaar is, is de daling van afgelopen jaar aanleiding geweest om vanuit DESAN en ROA een taakgroep non-respons te formeren. Deze taakgroep heeft een aantal voorstellen gedaan om de respons van de meting 1998 e.v. te verbeteren. De twee belangrijkste maatregelen bestaan uit het korter en aantrekkelijker maken van de vragenlijsten en het verloten van een prijs onder de respondenten. In het werkdocument van de meting 1998 zal geëvalueerd worden in hoeverre deze maatregelen hun effect hebben gehad.

\section{Literatuur}

Allen, J. P., G.W.M. Ramaekers (1998), De arbeidsmarktpositie van afgestudeerden van het hoger beroepsonderwijs. HBOMonitor 1997, Voorlichtingsdienst HBO-Raad, Den Haag.

Genugten, B.B. van der (1986), Inleiding tot de waarschijnlijkheidsrekening en mathematische statistiek deel 1, Stenfert Kroese, Leiden-Antwerpen.

ROA / DESAN (1998), De arbeidsmarktpositie van afgestudeerden van het hoger beroepsonderwijs. lienst HBO-RRBa; Den Haag.

ROA (1998a), Schoolverlaters tussen onderwijs en arbeidsmarkt 1997, ROA-R-1998/5, Maastricht.

ROA (1998b), Statistische bijlage. Schoolverlaters tussen onderwijs en arbeidsmarkt 1997, ROA-R1997/5B, Maastricht.

Velden, van der R.K.W., R.A.M.H.M. Welters en E.J.T.A. Willems, Economen op de arbeidsmarkt 1997 WO-monitor Economie, nog te publiceren.

Willems, E.J.T.A. en A.S.R. Van der Linden (1998), Methodiek schoolverlatersinformatiesysteem 1996, werkdocument, ROA-W1998/1. 


\section{Appendix A: Kernvragenlijst}

Tabel A.1

Overzicht kernvragen Schoolverlatersinformatiesysteem

Variabele

Opmerking

\section{Algemeen}

Geslacht

Leeftijd

Etniciteit

Toestemming doorgeven gegevens aan school

Onderwijsloopbaan

Gevolgde opleiding

Voltijd- of deeltijdvariant van gevolgde opleiding

$\mathrm{HBO} / \mathrm{WO}$

Begindatum gevolgde opleiding

Einddatum gevolgde opleiding

Diploma of certificaat behaald van gevolgde opleiding

Opnieuw kiezen van gevolgde opleiding

Hoogste vooropleiding

Vooropleiding voor hoogste vooropleiding

LLW of in-service opleiding

LLW of in-service werk of stageplaats

LLW of in-service diploma/gestopt

Aansluiting LLW of in-service opleiding op gevolgde opleiding

Opnieuw kiezen LLW of in-service opleiding

Vervolgopleiding

Voltijd- of deeltijdvariant van vervolgopleiding

Vervolgopleiding diploma/gestopt

Plaats van vervolgopleiding

Aansluiting vervolgopleiding op gevolgde opleiding

Opnieuw kiezen vervolgopleiding

Cursus/bedrijfsopleiding

Cursus/bedrijfsopleiding totale duur

Cursus/bedrijfsopleiding aantal uren per week

$\mathrm{LAO} / \mathrm{MBO} / \mathrm{HBO} / \mathrm{WO}$

$\mathrm{MBO} / \mathrm{HBO} / \mathrm{WO}$

$\mathrm{HBO} / \mathrm{WO}$

AVO/VBO/MBO

AVO/VBO/MBO

AVO/VBO/MBO

AVO/VBO/MBO

AVO/VBO(excl.LAO)

AVO/VBO(excl.LAO)

niet voor AVO

$\mathrm{MBO} / \mathrm{HBO} / \mathrm{WO}$

$\mathrm{MBO} / \mathrm{HBO} / \mathrm{WO}$

\section{Arbeidsmarktintrede}

Maatschappelijke positie sinds schoolverlaten

Verwijzing: (ook) betaald werk

Actief gezocht naar werk tijdens of na opleiding

Begin actief zoeken naar werk

Betaald werk gewenst aantal uren

Betaald werk laatste 4 weken gezocht

Beschikbaar betaald werk

Reden niet beschikbaar voor betaald werk

Inschrijving arbeidsbureau

Huidige functie begindatum

Huidige functie werving

Huidige functie beroep SBC 92

Huidige functie branche SBI 93

Huidige functie personeelsomvang bedrijf

bij kunst zowel betaalde als onbetaalde werkkringen

$\mathrm{MBO} / \mathrm{HBO} / \mathrm{WO}$

$\mathrm{MBO} / \mathrm{HBO} / \mathrm{WO}$

Tabel A.1 (vervolg) 
Huidige functie vestigingsplaats bedrijf

Huidige functie dienstverband

Huidige functie aanstelling

Huidige functie vereist opleidingsniveau volgens werkgever

Huidige functie vereist opleidingsniveau volgens schoolverlater

Huidige functie vereiste opleidingsrichting volgens werkgever

Huidige functie vereiste opleidingsrichting volgens schoolverlater

Huidige functie leidinggeven

Huidige functie arbeidsuren per week

Huidige functie bruto maandinkomen

Huidige functie aansluiting met gevolgde opleiding

Nevenfuncties

Nevenfuncties aantal uren per week

Opleiding-huidige functie: belang van kennis en technieken

Opleiding-huidige functie: belang van vaardigheden

Opleiding-huidige functie: belang van houdingsaspecten

Opleiding-huidige functie: aandacht voor kennis en technieken

Opleiding-huidige functie: aandacht voor vaardigheden

Opleiding-huidige functie: aandacht voor houdingsaspecten

Huidige functie werving

Huidige functie beroep SBC 92

Huidige functie branche SBI 93

Huidige functie personeelsomvang bedrijf

Huidige functie vestigingsplaats bedrijf

Huidige functie dienstverband

Huidige functie aanstelling

Huidige functie vereist opleidingsniveau volgens werkgever

Huidige functie vereist opleidingsniveau volgens schoolverlater

Huidige functie vereiste opleidingsrichting volgens werkgever

Huidige functie vereiste opleidingsrichting volgens schoolverlater

Huidige functie leidinggeven

Huidige functie arbeidsuren per week

Huidige functie bruto maandinkomen

Huidige functie aansluiting met gevolgde opleiding

Nevenfuncties

Nevenfuncties aantal uren per week

Opleiding-huidige functie: belang van kennis en technieken

Opleiding-huidige functie: belang van vaardigheden

Opleiding-huidige functie: belang van houdingsaspecten

Opleiding-huidige functie: aandacht voor kennis en technieken

Opleiding-huidige functie: aandacht voor vaardigheden

Opleiding-huidige functie: aandacht voor houdingsaspecten
$\mathrm{MBO} / \mathrm{HBO} / \mathrm{WO}$

niet bij LAO en kunst

niet bij AVO

niet bij AVO, LAO en kunst

\author{
LAO/MBO/HBO/WO \\ $\mathrm{MBO} / \mathrm{HBO} / \mathrm{WO}$ \\ $\mathrm{MBO} / \mathrm{HBO} / \mathrm{WO}$ \\ MBO (beperkt)/HBO/WO \\ MBO (beperkt)/HBO/WO \\ MBO (beperkt)/HBO/WO \\ MBO (beperkt)/HBO/WO \\ MBO (beperkt)/HBO/WO \\ MBO (beperkt)/HBO/WO \\ $\mathrm{MBO} / \mathrm{HBO} / \mathrm{WO}$
}

$\mathrm{MBO} / \mathrm{HBO} / \mathrm{WO}$

$\mathrm{MBO} / \mathrm{HBO} / \mathrm{WO}$

niet bij LAO en kunst

niet bij AVO

niet bij AVO, LAO en kunst

$\mathrm{LAO} / \mathrm{MBO} / \mathrm{HBO} / \mathrm{WO}$
$\mathrm{MBO} / \mathrm{HBO} / \mathrm{WO}$
$\mathrm{MBO} / \mathrm{HBO} / \mathrm{WO}$
$\mathrm{MBO}$ (beperkt)/HBO/WO
$\mathrm{MBO}$ (beperkt)/HBO/WO
$\mathrm{MBO}$ (beperkt)/HBO/WO
$\mathrm{MBO}$ (beperkt)/HBO/WO
$\mathrm{MBO}$ (beperkt)/HBO/WO
$\mathrm{MBO}$ (beperkt)/HBO/WO

LAO/MBO/HBO/WO

MBO/HBO/WO

MBO (beperkt)/HBO/WO

MBO (beperkt)/HBO/WO

MBO (beperkt)/HBO/WO

MBO (beperkt)/HBO/WO 